Encrucijada/Crossroads: An Online Academic Journal

Issue 1, Volume 12003

\title{
Working Text \\ Latinos and Cultural Exchange \\ De-Facing Mainstream Magazine Covers: The New Faces of Latino/a Transnational and Transcultural Celebrities
}

\author{
Alberto Sandoval-Sánchez \\ Professor of Spanish \\ Mount Holyoke College, MA
}

"Face it: this is going to be a bilingual country. Back in 1849, the California constitution was written in both Spanish and English, and we're headed that way again.

“These bilingual, bicultural [Latino/a] kids: isn't that America? They are amalgams of all kinds of ethnic influences. They are mirrors. I'm not sure if they are projecting or reflecting, maybe both."

Christy Haubegger, founder of Latina Magazine

Nineteen ninety-nine will always be remembered as the last year of the millennium when Latinos/as took over U.S. popular pop culture and its media. Ricky Martin, Jennifer Lopez, Enrique Iglesias, Mark Anthony, and Cristina Aguilera skyrocketed to number one in the Billboard Hit Parade. John Leguizamo starred in Spike Lee's film The Summer of Sam and received an Emmy for the HBO production of his Broadway hit Freak. Salma Hayek was the leading lady on the Hollywood screen in Wild Wild West. Carlos Santana made a "groovy" comeback with his recording megahit "Supernatural." In sports, Sammy Sosa's record-breaking home runs in baseball made him America's adopted migrant son. Papi chulo Oscar de la Hoya, who was the undefeated welterweight champion, lost his title to Felix Trinidad. His defeat was compensated with his resurgence as a celebrity and sex symbol on the Spanishspeaking network, Univision, appearing in all type of shows, commercials, and flirting with the possibility of a Spanish-language album.

In the Anglo-Saxon world of journalism, The New York Times had to make room in its leisure and arts section for the presence and prominence of Latino culture with articles such as: "On Menus, the Ticket Is Nuevo Latino" (6 January 1999); "For Latin Music, New Worlds to Conquer" (24 May 1999); "Another Latin Boom But Different" (27 June 1999); "The Face and Soul of a Barrio" (5 June 1999); “A Renaissance of Hispanic Artistry” (15 July 1999); 
"Latinos Gain Visibility in Cultural Life of U.S." (19 September 1999); "Media: After a Summer of High Profile Coverage of Hispanic Culture, Some Wonder If It Will Last" (4 October 1999). Major national magazines featured Latino special issues with Latinos/as on the cover: George Magazine named its special section "Latin Heat!: Salma Hayek and the New Latino Power Brokers Are Making America Sizzle" (July 1999); Time called it "Latin Music Goes Pop" (24 May 1999); and Newsweek concentrated on a new generation of Latinos/as with a coverage entitled "Latin U.S.A. How Young Hispanics Are Changing America" (12 July 1999). Needless to say Ricky with his "Living La Vida Loca" was the one and only on the covers of People, New York, Rolling Stone, Playgirl, Interview, TV Guide, and even in the gay publication The Advocate. On the MTV Video Music Awards he walked away with five awards, including Best Pop Video.

Latino/a faces and headlines had never appeared on most of these magazines covers; de hecho, for New York Magazine it was not since 1972 with its issue on Latin soul, "The Big Mango: Latin Impact on New York Style." On this occasion it went a step further: the magazine surprisingly changed its logo to Nueva York. It took Time a decade to cover Latinos since the publication of its special issue in July 1988 (when the Latino population was merely 15 million)_"Magnifico! Hispanic Culture Breaks Out of the Barrio." Then, they declared the Eighties to be the decade of "Hispanics." Such proclamation would not become effective until the last summer of the millennium, as if it foretold that the new millennium will be the time for the impetus, accomplishments, and economic and political impute of a young, talented, and energized Latino/a generation in the U.S.

This tremendous booming of Latino/a participation and visibility in the American national cultural arena entails more than a crossover into the mainstream. Neither this, nor a renaissance of an U.S. Latino/a presence in the Anglo-American cultural landscape is the outcome of spontaneous combustion, a passing trend, or a unique phenomenon. It bears witness to the fact that a demographic change has occurred, a new generation of U.S. Latinos/as has emerged, and-in a capitalist society as ours - this generation has a high consuming potential and represents a marketable target in a competitive and growing national and global economy with the movement of capital and work force. Statistics prophesy the dramatic growth of the Latino population in the new millennium: by the year 2005 Latinos will be the largest ethnic minority in the U.S.; by 2050 they will be nearly one quarter of the entire population. Presently, the Latino population is 31 million (that is $11 \%$ of the entire U.S. population), mostly living in New Mexico, California, New York, Florida, and Illinois. For a second generation of Latinos/as (and previous generations of Chicanos/as), the

Encrucijada/Crossroads 1.1 (2003): 13-24 
U.S. is and was always home. They are no crossovers: $60 \%$ were born here and have always spoken English, if not Spanglish.

Latinos/as are a marketable, profitable target and have a purchasing and spending power of about $\$ 300,000$ billion (500,000 by the year 2020). Advertising and media outreach strategies in Spanish also reflect the fact that $\mathrm{el}$ español is here to stay. Si se habla español, se venden más productos. Hoy día Spanglish es good business. Research has confirmed that Latinos/as are devoted buyers, as faithful to one brand as they are to familia. In the last decade Spanish has become the most popular foreign language in colleges and universities, despite the English Only movement and the conservative anti-bilingual education campaign in the West coast and the Southwest. Ironically, in the political arena, George Bush has displayed his fluency in Spanish and defined himself as a republicano compasivo to attract Latino/a voters. Are many Latinos/as willing to forget the rampant Republican xenophobia, anti-migration hysteria, and blatant racism with the Republican victory of proposition 187 in California in 1994, which denied illegal immigrants the right to public school education, health care, and public social services? The fact is that Latinos/as have become a voting power, an electoral population that cannot be ignored any more. Their vote will affect both local and presidential elections now and in the future, considering that a third of the Latino population is still under 18 and the median age is $26-$ ten years younger than the general population.

Since the 80s, with an increase of refugees and undocumented aliens from Central America, with a professional Latin American middle class resettled in Miami - the so called "Hispanic Hollywood" and "entertainment capital of Latin America"-and other cities, and with an increase of the usage of Spanish in music, media, advertising, politics, and urban barrios, American cities have become Latin American cities. In fact, Miami, Los Angeles, and New York have become the second largest cities of Cuba, Mexico, and Puerto Rico. 90\% of Latinos/as reside in cities. No wonder that the number one FM radio stations con sabor latino in Los Angeles, New York, and Chicago are broadcast Latino programming.

Now U.S. Latinos y latinoamericanos all inhabit la transfrontera; we all live in the Borderlands. Transnationalism has supplanted nationalism. Unfortunately, at a time when technology, the internet, and cable TV erase geographic distances, the Border between the U.S. and Mexico has been militarized, and illegal trespassers to the Land of Opportunity in search of the American Dream are being hunted, persecuted, abused, and even killed. Meanwhile, el español is circulating everywhere and a new generation of Latino/a faces in pop culture has invaded the mainstream cultural imaginary. No other media idiom registers this historical moment of the so-called "Latinization of America" and "Latin Explosion" as Anglo hegemonic national magazines do. It 
is crucial to unpack all these magazine covers in order to put into practice a critical reading of hegemonic ways of seeing and to raise questions about how race, class, ethnicity, sexuality, identity, politics, and culture articulate Latino/a experience and Latinidad in given relations of power.

For many Latinos/as this is a much waited for time of celebration and pride. By identifying with these celebrities, many Latinos/as see their crossover not simply as a sign of tokenism or a trendy Latin music craze. It evidences the presence and visibility of a new generation that cannot be marginalized, silenced, and underrepresented. Although these Latino/a superstars emblematize what it means to be a Latino/a in the entertainment world of globalization, they also put into question who is Latino/a, what is Latino identity, and which images of Latinidad predominate and circulate. No sólo eso, but it is necessary to question what is gained or lost in the act of crossing over. How much room is there for agency and transculturation when assimilation and English dominance are determining factors for stardom in the U.S.? Can Latinos/as be truly bilingual and bicultural in the entertainment industry? Can they escape dominant stereotypes of the "Latin domestic or foreign Other"? Why are Latinos/as, like African Americans, relegated to perform and succeed primarily in music and sports? When looking as a whole at all the magazines with Latino/a faces on the covers in 1999, how significant is it to observe whose faces are not there, what is left out, and how Latino/a identity and culture are represented through the faces of these stars? Most important, as Mireya Navarro stated sagaciously in an article published in the New York Times, 4 October 1999, "But how much coverage of Latinos - and what kind of coverage - can be expected after this Latin summer?" (C17).

There is no doubt that the tragic death of Selena in 1995 woke up the Anglo media and entertainment industry when millions of her Latino/a fans mourned her passing. People Magazine's coverage of the Latina star sold out overnight and a special tribute sold one million copies. Noticing the posthumous beatification of Selena-including the release of a crossover album with only six or seven songs in English-led the Anglo music business world to "discover" the marketing and consuming potential of Latinos/as, not only in the U.S. but in Latin America as well. Selena represented a Latino/a generation that could not be ignored and remain invisible in the Anglo cultural domain. Her brown face and skin, her bilingual and bicultural condition, her Mexican roots, her Tex-Mex music, her humble class origin, her mestiza identity, her border experience, made her the most monumental symbol for Latinos/as in the U.S. Selena will always be irreplaceable. If on the one hand there will always be a void in the Latino archives of memory for what she never got to accomplish, on the other hand she crossed social, cultural, and color barriers and opened the doors to the Latino renaissance that has taken over the Anglo entertainment industry. In a certain

Encrucijada/Crossroads 1.1 (2003): 13-24 
way, both Jennifer and Ricky are where they are thanks to Selena. Jennifer's portrayal of Selena in the movie Selena launched her acting career to celebrity status in the Anglo cinematic world, while her superb impersonation of Selena made her a Latina heroine and role model. As for Ricky, he was in the group Menudo, which made him a teenage idol in the Spanish language music world. In a way, he achieved the crossover move into the English market that Selena planned to conquer when killed. As a journalist observed in an article published in New York Magazine, September 1999, "Selena begat Jennifer (Menudo, of course, begat Ricky)" (23). Of course, I would add, Selena also begat Ricky.

What all these young Latino/a stars have in common is more than charisma, sex appeal, and electrifying personalities. They constitute a new Latino/a generation that is bilingual and bicultural. In each particular case, every one of them represents a border identity, a dual world of transculturation. Jennifer grew up in the Bronx submerged in Puerto Rican culture, in constant interaction with African Americans, and educated in the Anglo educational system. Mark Anthony grew up in El Barrio. Both have experienced marginality and both are proud of their Puerto Rican background. They are Puerto Ricans and they are Latinos/as; that is, they embrace their national and ethnic identities as well as a U.S. pan-Latino identity. In a way they are similar to Selena, for they inhabit the geo-political and cultural site of la frontera/el barrio where identities are always in the making, in fusion, in process, contradictory, heterogeneous, and porous. These transcultural identities are usually invalidated by Anglos and Latin Americans who claim to have a monolithic and homogeneous national identity. For example, Salma Hayek disqualified Jennifer as a Latina because she was born in New York and has no Spanish accent. This nationalist and Hispanophilic way of thinking places us in the dangerous terrain of cultural authenticity and assertion of superiority. Who has the right to make such judgments when taken into consideration that, in spite of Anglo imperialism, imposed assimilation in the educational apparatus with its English-only enforcement, and domestic colonialism, the Spanish language and Latino culture in the U.S. have survived through the centuries? It is necessary to emphasize the cultural fusion and exchanges between U.S. Latino culture and Latin America. It is incredible that Jennifer, Mark Anthony, and La India have crossed over to the Spanish market and have become the idols of salsa and Caribbean rhythms and sensibility. As a result, U.S. Latinos/as are being exposed to Spanish language as well as to Latin American culture and music. In this world of global techno-communication, Shakira, Elvis Crespo, Enrique Iglesias, Maná, Carlos Vives, Chayanne, Talía, and many other rock and pop stars, including Ricky, have all contributed to the construction and production of U.S. Latino/a identity and the reconnection and recovery of their Latin American roots. The problem is that they have appropriated the category "Latino/a" as they have relocated in Miami; 
consequently, marginalizing and excluding other talented U.S. Latinos/as. An exception is Cristina Aguilera, a born again "ultra blond" Latina, who is starting to record in Spanish after her smash hit "Genio en la botella." She is even learning Spanish for her complete crossover into Latin America and Spain.

It must be emphasized that Ricky is an exceptional case. His primary identity is that of a Puerto Rican who received a bilingual education in the Island and grew up listening to Anglo music. If U.S. Latinos/as are conditioned by the dynamics of domestic colonialism, Ricky must be placed within the context of imperial colonialism. Given that he has crossed over to the English music world, he is seen as a foreigner who has a good command of English, contributing in this way to perpetuate the stereotype of Latinos/as as foreigners and recent immigrants. At work here are two main issues: 1) his nationalistic posture and his promise to never assimilate, to never give up his Spanish language and culture, dismiss Puerto Rico's colonial status where Puerto Rican sovereignty is nonexistent and acculturation seems to be inevitable for many; and 2) his ignorance of racism in the U.S. and how Puerto Ricans are seen as people of color distances him from the trials and tribulations of U.S. Latinos/as in respect to their economic and social inequality. The second issue merits some specific attention for comprehending his socio-political positioning in the U.S. Latino geo-political landscape. In an interview in New York Magazine, June 1999, when asked for his opinion on U.S. Puerto Rican writer Esmeralda Santiago's statement made in Time, May 1999-that dark skinned Latins still cannot land a contract-his response shows how unattached he is from the U.S. Puerto Rican experience in matters of race and class and how ignorant he is about the experiences of people of color in the U.S.:

I can't get anymore Latin! It's so racist to say that because you are dark skinned you cannot make it in America. Whoever wrote that should go to jail or at least get sued. It makes me angry. People forget that there's a long list of artists who have been doing this for so many years, like Jose Feliciano, Gloria Estefan, Santana played Woodstock! So this so-called led Latin movement isn't new. There are a lot of artists in Latin America who have all the tools to cross over. It will happen. It's just not there yet. (45)

First of all, he does not understand the complexity of racism in the U.S.; second, he takes for certain Latino/a visibility, participation, and accessibility to opportunity in the entertainment industry by only naming three celebrities; third, he overlooks the history of racism and stereotyping on Broadway, Hollywood, and television; and fourth, for him a Latino is someone from Latin America. Martin, like Salma and most of the entertainment community in Miami, identifies a priori with Latin Americans rather than with U.S. Latinos/as. Furthermore, the 
entertainment world fetishizes white bodies according to their own practices and ideologies of racism. There are more white faces to come among the Latin American crossovers. Wait until Talía, Carlos Ponce, Elvis Crespo, and others make their debut in English. The question is who is crossing over, and which faces are represented? Where is Selena's face? Esmeralda Santiago was right when pointing out in her Time interview that the new pop Latin wave could use some skin-tone diversity: "It's fascinating to me, and a little upsetting, that this is still the white face of the Caribbean. I'm sure that there are equally talented and gifted artists out there whose facial features don't conform as much to the European ideal." (78). Like Santiago's point of view, some have noticed how Jennifer has whitened: she has become more polished, articulate, refined, and "blonded." In New York Magazine, September 1999, she herself has stated: "I've actually changed the way I talked, I've changed the way I move my hands" (67). Under this pressure, what has the Latina face sacrificed to become the face of L'Oreal? Given that the notion of beauty is a social construct and whiteness a sign of power, it is meaningful here to consider how does the Caucasian and European model of beauty and race mold Latino/a faces in their crossover. In addition, where are the Chicano/a faces when $60 \%$ of the Latino population is Mexican American? Where are the Black Latinos/as? Where are the "Amerindian"/mestizo/a faces? How can difference be acknowledged, without essentializing identity, in such heterogeneous, hybrid, and diverse ethnic and racial populations? How inclusive can Latino/a identity be when twenty-two nations are at stake with their own definitions of nationalism, ethnicity, and race - a predicament that is also applicable to U.S. Latinos in all their plurality?

As with race, when discussing U.S. Latino/a identity, the issue of class must be tackled. Crossing over implies social mobility and making it big. For U.S. Latinos/as performers, like Jennifer and Mark Anthony, and even for Selena, who have working class baggage, their success materializes the American Dream. By accentuating the individual aspect-of "if-I-made-it-others-can," these superstars erase and overlook socio-historical factors that affect Latino reality in the U.S. For example, on a visit to a grade school in Queens, Jennifer promotes such an ideology by universalizing and dehistoricizing her own experience: "I'm here to tell you-because I started out exactly were you are-don't let anyone tell you you can't do anything you want, because you can" (cited in Elle, July 1999, 169). Actually, how many Latinos/as can really make it? It is amazing that the new generation identifies with these crossover dreams of fame and affluence. Latino/a pop stars have become cultural heroes, a source of inspiration, pride, and cultural affirmation. Latino/a fans believe in them, los adoran, even when some celebrities, like Salma, have class biases. In an interview published in George, July 1999, she comments to the journalist after Latinos asked her for autographs 
the following: "I'd rather see people selling my autographs than robbing houses" (188).

Returning to the issues of Latino/a identity and representation, besides race and class, sexuality cannot be left aside for two reasons: the extreme gendered behavior that characterizes masculinity and femininity in the Latin American and U.S. Latino communities and the constant behavioral exhibition of compulsory heterosexuality. All these idols are regulated and defined by the demands of heterosexual politics and horizon of expectations that make of them sex symbols. For example, Jennifer has been called a seductive and voluptuous goddess, a supreme bombshell-images that make of her body a site of eroticism, desire, pleasure, and exoticism. Both Jennifer and Salma in publicity photographs have rendered their bodies sexually desirable as if they were Playboy centerfolds. (See Elle and Vibe). As for Jennifer, her biggest asset in mainstream culture is her ass. Sadly, she has become a target of sexist, chauvinist, and racist jokes. Even in major music award shows such as MTV Music Awards and American Music Awards, the male hosts opened the event with vulgar and humiliating jokes about her body shape. VH1 in its Pop-Up Video program overdoes the usage of the preposition "but" to ridicule, and I would accentuate, further humiliate, the rising Latina pop star. It has become such an obsession that this kind of vulgar behavior must be read within the parameters of the Eurocentric imperialist gaze of the Other. In this context, Jennifer represents the stereotype of passion, uncontrollable desire, corporeal abundance, and sexual energy that characterizes people of color. Her ass echoes the European fascination with the HOTTENTOT VENUS: her body is turned into a spectacular object embodying the racist spectacle of the Other. To gain her agency, she has been forced to justify and explain her racial and ethnic body:

I look at it in a positive way ['cause I'm representing']... women out there who are shaped like me are not ashamed of it. [...] And [it's] nothing to be ashamed of. All the women in my family looked exactly the way I do and I thought they were the most beautiful things in the world. (Elle, July 1999, 188)

She can only hope for the time when her butt will not further be the center of attraction and attention: "I would love to read an article where it is not even mentioned" (Vibe, August 1999, 104).

Jennifer's struggle with racial stereotypes and sexism also cannot be disconnected from the dominant Hollywood stereotypes of Latinas as spitfires, femme fatales, and bombshells. Within the Anglo cultural imaginary the stereotypical images of Carmen Miranda, Lupe Velez, Rita Moreno, Dolores del Rio, and Charo can be accessed, activated, and put into circulation at any given moment. More than Jennifer, Salma, who is the cover girl for Revlon, perpetuates 
with her Spanish accent the image of U.S. Latinos/as as foreign Other and immigrants (like Maria and the Sharks in West Side Story). (This also applies to Antonio Banderas, Sammy Sosa, Shakira, and Ricky.) Racist stereotypes are put in circulation even with Salma when a journalist describes her in the following fashion: "Hayek regards me with the stone cold face of an Aztec goddess" (George, July 1999, 87). The star, the daughter of a retired opera singer and a successful Lebanese businessman cannot escape American racism. She can only be conceived in racial terms: she has a racialized face, and the face of the Aztec race is superimposed over the glamorous face of Revlon.

In the Anglo cultural web of Latin stereotypes even Ricky gets entangled. Because his hip shaking and agitated erotic rhythm of his pelvis allude to Latino sexuality, he becomes a sex object that embodies the ultimate representation of exotic masculinity, unequivocally projecting the image of the Latin lover living his "vida loca." He is framed within images of passion, chaos, fiesta, pleasure, noise, liberation - a state of being and doing that is opposite to the Anglo rational world and controlled body language. Despite his own commitment and mission to undo stereotypes, Ricky will have a long journey to walk for implementing his political agenda: "But I had a mission and the mission was to get rid of stereotypes and make people understand a little bit more of what a Latin performer, Latin sound, can be" (New York Magazine, June 1999, 44). "I wanted my performance to change stereotypes. It's a mission I guess we all have, and I just wanted to bring something refreshing, maybe something futuristic" (Interview, June 1999, 102). Certainly, his missionary campaign is well exemplified in his refusal to do a West Side Story remake starring with Jennifer: "It would represent gangs and stereotypes about my culture" (Newsweek, 31 May 1999, 72). In these terms, this new generation does not have to sacrifice their cultural roots (like other Latinos/as did in the past), can somehow resist assimilation, and can counterattack offensive and negative representations of Latinos/as. However, stereotypes are always there, waiting for mobilization. The best example is Ricky's song "Spanish Eyes." He meets a woman in Rio at the carnival and dances a tango with her. This cultural and geographic nightmare gets out of hand with a flamenco singer in the background and as the flamenco rhythm by mid song turns into salsa, Caramba, what a mess! Carmen Miranda did the same in the 40s. And we thought we had come a long way...

What is fascinating about Ricky is how his sexuality has been packaged as a heterosexual man who embraces his gay following. The best attempt to advertise his assumed heterosexuality is his cover picture in Rolling Stone of August 1999, which exposes his sexy midriff skin while he floats in a simulated swimming pool. Compulsory heterosexuality is reinforced by framing him with naked bodies of white women who float around him like in a Ziegfield choreography. It is the headline that safeguards his hetero identity by anchoring 
him within the discursive realm and horizon of expectations of compulsory heterosexuality: "Ricky gets Deep Talking Sex, Love, Marriage \& Yoga." But is it that fácil to pin down Ricky as a heterosexual? His picture on the cover of The Advocate, July 1999, where he poses seductively under a headline that reads "The Gay Connection," complicates his sexual preference, but does not "out" his sexual orientation. The article leaves more to the imagination rather than give an answer, however it makes explicit his tolerance to gay fans, his cross-gender appeal, and points out his ambiguity when asked about his sexuality. Despite gay rumors, he has incredibly succeeded keeping his privacy in place, as he has openly insisted: "But what I say about sexuality is, I leave it for my room and I lock the door. I go back to my culture. It's something you don't talk about. At home you don't talk about it" (Interview, June 1999, 104). In New York Magazine, July 1999, he again addresses his sexuality in all its ambiguity:

....in the end, it's my space, it's my house, and it's not only for me, but also I have a mother, and I have a sister and brothers, and I have a father. And some people want to cause them pain. People are out there just wanting to destroy it. They see you happy; they don't like when they see you happy. They just want to break that magic. So you've got to ignore them and just pray for those souls that just want to do you harm. I don't own them anything.

Is he saying that he is gay without saying it? Are we supposed to read between the lines? Why the silence? Why is he so reluctant to come out if he is gay? More important than answering these questions is to observe how he finds refuge in Latin American, Spanish, and Latino cultures where homophobia is the law and homosexuality is taboo. Can it be that in this computerized age of ours, where the preponderance of the digital image over the real body/person prevails, the manufactured Ricky in video, CDs, and on the Internet eludes real body-tobody contact and sexual acts? If so, Ricky incarnates a new sexuality that makes him a safe-sex symbol in our new construction of the body and practices of sexuality in the time of AIDS. Furthermore, after silencing homosexuality, he goes a step further: he intervenes advocating compassion for Latino gay men with AIDS:

... and I talk about AIDS. There is a song [on my last album] Vuelve that means: "Thanks for thinking about me." It was written by Renato Russo, a great person and composer who died because of AIDS. He wrote this song right before he passed away. I have to do something to keep his music alive." (Interview, June 1999, 105).

Encrucijada/Crossroads 1.1 (2003): 13-24 
By doing so, Ricky emerges as a cool guy who exposes his friendship with gay men, an act that also implies his interaction with a gay world. He is known for "LIVING LA VIDA LOCA" and he is well aware of the vida de las locas, yet that does not mean that he has to announce that he is loca (common word for gay), since culturally that it is not permissible. In the end, he is just a hot commodity who crosses all borders and in doing so he evades any fixation: his music blurs all genres and his sexual identity depends on his fans' sexual orientation.

For some, the euphoria accompanying the Latino/a music crossover constitutes the ultimate commodification of Latino culture. Some lament that it has overshadowed real issues like school dropouts, AIDS, delinquency, domestic abuse, teenage pregnancy, underemployment, poverty, and other types of social ills affecting Latino communities. Some allege that what has taken place is the mainstreaming of Latino music in English and not the embracing of Latinos/as, Latino culture, and Spanish language. Mark Anthony's declaration is enough evidence for those who assume such a position: "We are not doing Latin music on our English stuff. Latintinged, yes" (Time, May 1999; 79). Some resent that all Latinos/as are dumped in the same shopping bag without considering differences.

La verdad es que all these performers have complicated what it means to be a Latino/a. As Edward James Olmos told Jennifer: "You are very important to your community." (Elle, July 1999, 170). As ambassadors, under the pressure of the burden of representation, they have the most difficult task to accomplish; that is, to represent Latinos/as and Latinidad. No se puede ignorar que all of them have achieved a status of cultural heroes. Like it or not, they are redefining and reimagining the American Dream and what it means to be an American. It cannot be denied that as they cross over they are not only leaving home but also searching for a route to come back, whatever that means en español or English. Jennifer is a visionary in this manner when explaining why she entitled her album On the 6, referring to the subway line in NYC that goes to the Bronx: "On the 6 'cause that's how I got where I was going, but it was also how I'd get back home" (Elle, July 1999, 169).

By emphasizing their border identities, by singing in Spanish and English, by advancing Latinidad, Latino/a performers are undermining the appropriation of "America" by Anglo imperialism and ethnocentrism. They are redrawing the map of the hemispheres and forging a new notion of the Americas. In these terms, to be a Latino means to recover a past, a cultural heritage from Latin America and to place our selves within a Latin American and Latino/a identity continuum that validates and legitimates U.S. Latino/a identities. Just a mere act of having a Spanish surname, of being dark skinned, of eating ethnic foods, of being a child of a mixed marriage, of dancing salsa or quebradita or merengue, of speaking some Spanish words or willing to learn Spanish, of buying records by Latino/a or 
Latin American pop idols, of watching Spanish TV, of taking Latino courses in college, of going to a concert, of collecting magazines with Latino/a faces on the covers, makes a new generation of Latinos/as practitioners of Latinidad. Nineteen ninety-nine showed that U.S. Latinos/as, Latinidad, and el español are alive and well in the U.S.: Nuestra América is still ours y lo será en el new millennium.

Encrucijada/Crossroads 1.1 (2003): 13-24 